УДК 634.7

DOI: $10.17238 / 0536-1036-2021-2-21-29$

\title{
OBTAINING HIGH-QUALITY PLANTING MATERIAL OF FOREST BERRY PLANTS BY CLONAL MICROPROPAGATION FOR RESTORATION OF CUTOVER PEATLANDS
}

\author{
Sergey S. Makarov ${ }^{1}$, Candidate of Agriculture, Senior Research Scientist; \\ ResearcherID: AAB-4651-2021, ORCID: https://orcid.org/0000-0003-0564-8888
}

Irina B. Kuznetsova ${ }^{2}$, Candidate of Agriculture, Assoc. Prof.; ResearcherID: $1 A B-4568-2021$,

ORCID: https://orcid.org/0000-0001-5011-3271

Anton I. Chudetsky', Leading Engineer; ResearcherID: H-1210-2019,

ORCID: https://orcid.org/0000-0003-4804-7759

Sergey A. Rodin', Doctor of Agriculture, Academician of RAS, Deputy Director for Research; ORCID: https://orcid.org/0000-0002-8947-9809

${ }^{1}$ Central-European Forest Experiment Station, ARRISMF, prosp. Mira, 134, Kostroma, 156013, Russian Federation; e-mail: makarov_serg44@mail.ru, a.chudetsky@mail.ru ${ }^{2}$ Kostroma State Agricultural Academy, ul. Uchebnyy gorodok, 34, pos. Karavayevo, Kostroma district, Kostroma region, 156530, Russian Federation; e-mail: sonnereiser@yandex.ru ${ }^{3}$ All-Russian Research Institute of Silviculture and Mechanization of Forestry, ul. Institutskaya, 15, Pushkino, Moscow region, 141202, Russian Federation

\begin{abstract}
The results of studies on the improvement of technology for producing highquality planting material of half-high blueberry and Arctic bramble by the method of clonal micropropagation are presented in the current paper. Creation of forest berry plantations in peat extraction areas allows reducing environmental damage and significantly increasing the efficiency of the timber industry. In recent decades, there has been an increasing interest in the creation of forest berry plantations on drained and cutover peatlands in Russia and other countries. It is necessary to use varietal planting material for the successful cultivation of forest berry plants on an industrial scale. Clonal micropropagation is the most effective of the vegetative methods for obtaining planting material, which allows receiving a huge amount of healthy planting material all year round in the conditions of a small laboratory area. Chloride-free ecosterilizer and bleaching agent based on sodium hypochlorite "Belizna" with an exposure of 15 and 20 min showed high efficiency in sterilization of explants of half-high blueberry and Arctic bramble. The highest viability of explants of the studied forest berry crops was observed when sterilized with a $0.1 \%$ mercuric chloride solution and $15 \mathrm{~min}$ exposure, and its sharp decrease at 20 min exposure. At the stage of micropropagation, with an increase in the concentration of cytokinin 6-BAP from 0.5 to $1.0 \mathrm{mg} / \mathrm{L}$ on the nutrient Woody Plant Medium the number of shoots in regenerated plants of half-high blueberry (Northcountry and Northblue cultivars) and Arctic bramble (Anna and Sofia cultivars) increased. The effect of the concentration of IBA-derived auxin on the number and length of roots of regenerated plants was observed at the in vitro rooting stage.

For citation: Makarov S.S., Kuznetsova I.B., Chudetsky A.I., Rodin S.A. Obtaining HighQuality Planting Material of Forest Berry Plants by Clonal Micropropagation for Restoration of Cutover Peatlands. Lesnoy Zhurnal [Russian Forestry Journal], 2021, no. 2, pp. 21-29. DOI: $10.17238 / 0536-1036-2021-2-21-29$
\end{abstract}

Keywords: Arctic bramble, clonal micropropagation, cultivar, cutover peatlands, growth regulator, half-high blueberry, in vitro.

\section{Introduction}

The negative environmental consequences of peat excavations include the violation of the unique ecological marsh systems, the deterioration of the living 
conditions of marsh and forest flora and fauna, and the associated reduction in the number of its populations up to complete destruction, as well as a decrease in the reserves of ground, underground and surface waters. In addition, valuable berry and medicinal plants growing in swamps are destroyed significantly, and the likelihood of peat fires increases, as a result of which a huge amount of smoke and other peat combustion products that can be transported over distances of tens and hundreds of kilometers are released into the atmosphere.

The reclamation of cutover peatlands is one of the important issues of forestry. Creation of plantations of forest berry plants in peat extraction areas allow to reduce environmental damage and significantly increase the efficiency of the forest industry. In recent decades, in Russia, as in other countries of the world, there is a growing interest in the creation of plantations of forest berry plants on drained and cutover peatlands. For these purposes, it is best to use berry crops that have traditionally grown in forest biocenoses, such as blueberry, cranberry, lingonberry and Arctic bramble. This is becoming increasingly important due to the constantly increasing anthropogenic load, as a result of which the resources of wild forest berry crops are steadily decreasing, their productivity is decreasing, and their quality is deteriorating $[6,13,19]$.

It is necessary to use varietal planting material for successful plantation cultivation of forest berry plants on an industrial scale. Selection of forest berry crops is carried out by both Russian and foreign scientists. So far, Russian varieties have already been created and hybrid forms of forest berry plants have been selected. These varieties and hybrid forms are promising for cultivation in southern taiga and coniferous-deciduous forest areas of the European part of the Russian Federation.

Such forest berry crops as blueberry and Arctic bramble can be successfully used for the recultivation of cutover peatlands. The fruits of these forest berry plants are dietary products with high nutritional value. They contain vitamins and biologically active substances necessary for the normal functioning of the human body. Moreover, these plants have medicinal properties. For example, blueberry fruits are rich in vitamin $\mathrm{P}$ substances that regulate the functioning of endocrine glands, have anti-inflammatory and antitumor effects, and are effective in prevention and treatment of atherosclerosis, hypertension, rheumatism and other diseases [1, $3,9,17,18,20]$. Arctic bramble fruits are used in folk medicine as an antizingotic, antipyretic agent, as well as for kidney stone disease, gout, gastritis, colitis, anemia, acute respiratory diseases, and bronchial asthma. Fresh leaves are used for wound healing, and tincture of leaves is used for rheumatism $[2,4,5,7,15]$.

Blueberry and Arctic bramble can be propagated both by seeds and by stem and root cuttings (vegetative), as well as by using in vitro tissue cultivation. It should be taken into account that that plants produced by seed propagation do not retain the features of the original mother variety, therefore this method is not suitable for varietal plants. Clonal micropropagation is the most effective of vegetative methods of obtaining planting material. This method allows receiving in conditions of small laboratory area a huge amount of healthy (virus-free) planting material all year round $[10,11]$.

\section{Materials and methods}

Our studies are devoted to improving the technology for producing highquality planting material of high-half blueberry and Arctic bramble using the clonal micropropagation. The research was carried out in the Laboratory of Clonal Micropropagation of Plants on the basis of the Central European Forest Experimental 
Station of the All-Russian Research Institute for Silviculture and Mechanization of Forestry in 2018-2019. As research objects We used two cultivars of high-half blueberry (Northblue and Northcountry), obtained by crossing $V$. corymbosum and V. angustifolium $[8,12,14]$, and two cultivars of Arctic bramble (Rubus arcticus L., Anna and Sofia) [16].

At the stage of introduction to in vitro culture, we studied the effect of various sterilizers with different exposures on the viability of explants of high-half blueberry and Arctic bramble. We used mercuric chloride (0.1\% solution), chloride-free ecosterilizer and bleaching agent based on sodium hypochlorite "Belizna" as the main sterilizers, with exposures of 10,15 and $20 \mathrm{~min}$. After 14 days, the viability of explants was determined by the ratio of live explants to the total number introduced into the culture. In each variant, 100 explants were introduced. Also we carried out a series of experiments to study the effect of cytokinin 6-BAP at the concentrations of 0.5 and $1.0 \mathrm{mg} / \mathrm{L}$ on the biometric parameters of shoots and IBA-derived auxin at the concentrations of 0.5 and $1.0 \mathrm{mg} / \mathrm{L}$ on in vitro rhizogenesis. Plants were cultivated on the Woody Plant Medium (WPM) with $\mathrm{pH}$ in the range of 4.5-4.8. The number and length of shoots and roots were recorded. 10-fold repeat.

\section{Results and discussion}

At the stage of in vitro culture introduction, we found that the ecosterilizer and bleaching agent were the most effective at an exposure of 15 and 20 min, where the explant viability was $75-91 \%$. The explants viability of both berry crops is quite high $(80-90 \%)$ when treated with corrosive sublimate for $15 \mathrm{~min}$, but it sharply decreased to $25-28 \%$ with an increase in exposure to $20 \mathrm{~min}$. This is apparently due to the phytotoxicity of mercuric chloride. The percentage of viable explants when treated with the studied sterilizing agents (except chloride-free ecosterilizer) was very low $(20-24 \%)$ at an exposure time of $10 \mathrm{~min}$ (table 1). The rest explants died from infection.

Table 1

The explants viability of high-half blueberry and Arctic bramble depending on sterilizing agents and exposure

\begin{tabular}{|c|c|c|c|c|c|c|}
\hline \multirow{2}{*}{$\begin{array}{c}\text { Sterilization } \\
\text { time, min }\end{array}$} & \multicolumn{4}{|c|}{ High-half blueberry } & \multicolumn{3}{c|}{ Arctic bramble } \\
\cline { 2 - 7 } & $\begin{array}{c}\text { Mercuric } \\
\text { chloride }\end{array}$ & $\begin{array}{c}\text { Chloride-free } \\
\text { ecosterilizer }\end{array}$ & $\begin{array}{c}\text { Bleaching } \\
\text { agent }\end{array}$ & $\begin{array}{c}\text { Mercuric } \\
\text { chloride }\end{array}$ & $\begin{array}{c}\text { Chloride- } \\
\text { free } \\
\text { ecosterilizer }\end{array}$ & $\begin{array}{c}\text { Bleaching } \\
\text { agent }\end{array}$ \\
\hline 10 & 20 & 50 & 15 & 24 & 56 & 22 \\
\hline 15 & 90 & 90 & 75 & 80 & 91 & 80 \\
\hline 20 & 25 & 95 & 95 & 28 & 93 & 91 \\
\hline
\end{tabular}

At the stage of micropropagation itself, increasing the concentration of cytokinin 6-BAP from 0.5 to $1.0 \mathrm{mg} / \mathrm{L}$ on the WPM medium increased the number of shoots in regenerated plants of high-half blueberry cultivars Northcountry and Northblue and Arctic bramble cultivars Anna and Sofia. At the concentration of 6-BAP $0.5 \mathrm{mg} / \mathrm{L}$ the number of shoots of high-half blueberry and Arctic bramble was 
2.1-2.4 and 2.5-2.6 pcs, respectively. At the concentration of $1.0 \mathrm{mg} / \mathrm{L}$ it was $3.2-3.5$ and $4.6-4.7 \mathrm{pcs}$, respectively. No significant differences were found in the studied cultures depending on the variety (table 2 ).

Table 2

The number of shoots of high-half blueberry and Arctic bramble depending on the cultivar and 6-BAP concentration, pes

\begin{tabular}{|c|c|c|c|c|}
\hline \multirow{2}{*}{ Species } & \multirow{2}{*}{ Cultivar } & \multicolumn{2}{|c|}{ 6-BAP concentration, } & \multirow{2}{*}{ LSD $_{05}$} \\
\cline { 3 - 4 } & & 0.5 & 1.0 & \\
\hline \multirow{2}{*}{ High-half blueberry } & Northblue & 2.1 & 3.5 & 1.41 \\
\cline { 2 - 4 } & Northcountry & 2.4 & 3.2 & 1.93 \\
\hline \multirow{2}{*}{ Arctic bramble } & Anna & 2.6 & 4.6 & 0.13 \\
\cline { 2 - 4 } & Sofia & 2.5 & 4.7 & 0.22 \\
\hline
\end{tabular}

$\mathrm{LSD}_{05}$ - least significant difference at $5 \%$ significance level.

The average shoot length of high-half blueberry cultivars Northblue and Northcountry with an increase in cytokinin 6-BAP in the nutrient medium slightly decreased from $3.9-4.1 \mathrm{~cm}$ at $0.5 \mathrm{mg} / \mathrm{L}$ to $3.0-3.3 \mathrm{~cm}$ at $1.0 \mathrm{mg} / \mathrm{L}$. A similar pattern was observed for Arctic bramble: the average length was $1.5-1.7 \mathrm{~cm}$ at the concentration of 6-BAP $0.5 \mathrm{mg} / \mathrm{L}$, and $1.1-1.2 \mathrm{~cm}$ at $1.0 \mathrm{mg} / \mathrm{L}$ (table 3 ).

Table 3

The average shoot length of high-half blueberry and Arctic bramble depending on the cultivar and 6-BAP concentration, $\mathrm{cm}$

\begin{tabular}{|c|c|c|c|c|}
\hline \multirow{2}{*}{ Species } & \multirow{2}{*}{ Cultivar } & \multicolumn{2}{|c|}{ 6-BAP concentration, mg/L } & \multirow{2}{*}{ LSD $_{05}$} \\
\cline { 3 - 4 } & & 0.5 & 1.0 & \\
\hline \multirow{2}{*}{ High-half blueberry } & Northblue & 4.1 & 3.0 & 0.29 \\
\cline { 2 - 5 } & Northcountry & 3.9 & 3.3 & 0.47 \\
\hline \multirow{2}{*}{ Arctic bramble } & Anna & 1.5 & 1.2 & 0.05 \\
\cline { 2 - 4 } & Sofia & 1.7 & 1.1 & 0.08 \\
\hline
\end{tabular}

The total shoot length in both studied berry crops was greater at the concentration of 6-BAP $1.0 \mathrm{mg} / \mathrm{L}$ and reached $10.5-10.6 \mathrm{~cm}$ for half-high blueberry and $5.2-5.5 \mathrm{~cm}$ for Arctic bramble. It was $8.6-9.4 \mathrm{~cm}$ and $3.9-4.2 \mathrm{~cm}$, respectively, at the concentration of 6-BAP $0.5 \mathrm{mg} / \mathrm{L}$ (fig.).

There were no significant differences in both berry crops depending on the cultivar (table 4).

Table 4

The total shoot length of high-half blueberry and Arctic bramble depending on the cultivar and 6-BAP concentration, $\mathrm{cm}$

\begin{tabular}{|c|c|c|c|c|}
\hline \multirow{2}{*}{ Species } & \multirow{2}{*}{ Cultivar } & \multicolumn{2}{|c|}{ 6-BAP concentration, $\mathrm{mg} / \mathrm{L}$} & \multirow{2}{*}{ LSD $_{05}$} \\
\cline { 3 - 4 } & & 0.5 & 1.0 & \\
\hline \multirow{2}{*}{ High-half blueberry } & Northblue & 8.6 & 10.5 & 0.60 \\
\cline { 2 - 4 } & Northcountry & 9.4 & 10.6 & 0.34 \\
\hline \multirow{2}{*}{ Arctic bramble } & Anna & 3.9 & 5.5 & 0.19 \\
\cline { 2 - 4 } & Sofia & 4.2 & 5.2 & 0.33 \\
\hline
\end{tabular}




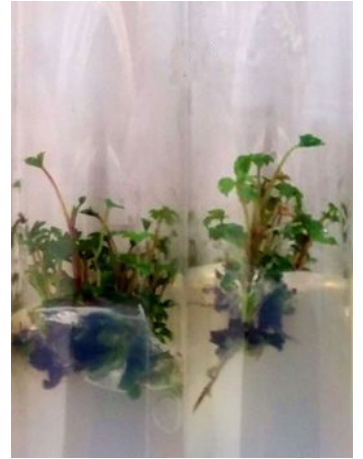

$a$

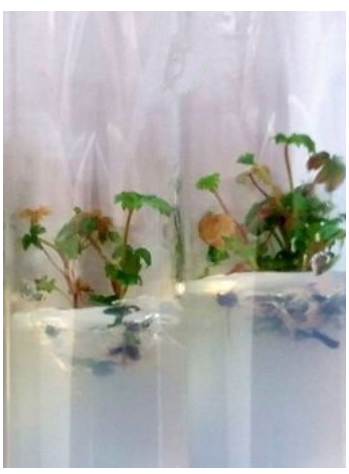

$b$

Arctic bramble plants in vitro at the stage of micropropagation itself with the addition of 6-BAP to the nutrient medium in the following concentrations, $\mathrm{mg} / \mathrm{L}: a-1.0 ; b-0.5$

At the in vitro rooting stage, we studied the effect of IBA-derived auxin concentrations on the number and length of roots of regenerated plants of high-half blueberry and Arctic bramble. The number of roots increased from 1.9-2.1 up to 3.9$4.1 \mathrm{pcs}$ for half-high blueberry with an increase in the concentration of IBA-derived auxin in the nutrient medium from 0.5 to $1.0 \mathrm{mg} / \mathrm{L}$, and from $3.7-3.8$ to $4.5-4.6 \mathrm{pcs}$ for Arctic bramble. Significant differences in the cultivars of the studied berry crops by the number of roots were not detected (table 5).

Table 5

The number of roots of high-half blueberry and Arctic bramble depending on the cultivar and IBA-derived auxin concentration, pcs.

\begin{tabular}{|c|c|c|c|c|}
\hline \multirow{2}{*}{ Species } & \multirow{2}{*}{ Cultivar } & \multicolumn{2}{|c|}{ IBA-derived auxin concentration, } & \multirow{2}{*}{ LSD $_{05}$} \\
\cline { 3 - 4 } & & 0.5 & 1.0 & \\
\hline \multirow{2}{*}{ High-half blueberry } & Northblue & 1.9 & 4.1 & 0.34 \\
\cline { 2 - 5 } & Northcountry & 2.1 & 3.9 & 0.41 \\
\hline \multirow{2}{*}{ Arctic bramble } & Anna & 3.8 & 4.5 & 0.69 \\
\cline { 2 - 4 } & Sofia & 3.7 & 4.6 & 0.51 \\
\hline
\end{tabular}

The average root length decreased slightly with increasing concentration of IBA-derived auxin. It was $1.5-1.6 \mathrm{~cm}$ at $0.5 \mathrm{mg} / \mathrm{L}$, and $1.3 \mathrm{~cm}$ at $1.0 \mathrm{mg} / \mathrm{L}$ for half-high blueberry, and 1.1-1.2 and 0.8-0.9 cm, respectively, for Arctic bramble. There were practically no differences in the average root length of both berry crops depending on the cultivar (table 6).

Table 6

The average root length of high-half blueberry and Arctic bramble depending on the cultivar and IBA-derived auxin concentration, cm

\begin{tabular}{|c|c|c|c|c|}
\hline \multirow{2}{*}{ Species } & \multirow{2}{*}{ Cultivar } & \multicolumn{2}{|c|}{ IBA-derived auxin concentration, } & \multirow{2}{*}{ LSD $_{05}$} \\
\cline { 3 - 4 } & & 0.5 & 1.0 & \\
\hline \multirow{2}{*}{ High-half blueberry } & Northblue & 1.6 & 1.3 & 0.45 \\
\cline { 2 - 5 } & Northcountry & 1.5 & 1.3 & 0.52 \\
\hline \multirow{2}{*}{ Arctic bramble } & Anna & 1.1 & 0.9 & 0.13 \\
\cline { 2 - 4 } & Sofia & 1.2 & 0.8 & 0.18 \\
\hline
\end{tabular}


The total root length of half-high blueberry was increased from $3.0-3.1 \mathrm{~cm}$ to $5.1-5.3 \mathrm{~cm}$ with an increase in the concentration of IBA-derived auxin from 0.5 to $1.0 \mathrm{mg} / \mathrm{L}$. It decreased from $4.2-4.4 \mathrm{~cm}$ to $4.1-4.2 \mathrm{~cm}$ for Arctic bramble. Cultivar differences in the total root length were not significant (table 7).

Table 7

The total root length of high-half blueberry and Arctic bramble depending on the cultivar and IBA-derived auxin concentration, $\mathrm{cm}$

\begin{tabular}{|c|c|c|c|c|}
\hline \multirow{2}{*}{ Species } & \multirow{2}{*}{ Cultivar } & \multicolumn{2}{|c|}{$\begin{array}{c}\text { IBA-derived auxin } \\
\text { concentration, } \mathrm{mg} / \mathrm{L}\end{array}$} & \multirow{2}{*}{ LSD $_{05}$} \\
\cline { 3 - 4 } & & 0.5 & 1.0 & \\
\hline \multirow{2}{*}{ High-half blueberry } & Northblue & 3.0 & 5.3 & 0.74 \\
\cline { 2 - 4 } & Northcountry & 3.1 & 5.1 & 0.93 \\
\hline \multirow{2}{*}{ Arctic bramble } & Anna & 4.2 & 4.1 & 0.69 \\
\cline { 2 - 4 } & Sofia & 4.4 & 3.7 & 0.97 \\
\hline
\end{tabular}

Thus, a change in the concentration of IBA-derived auxin influenced the number of roots, the average root length and the total root length of high-half blueberry and Arctic bramble plants.

\section{Conclusion}

The following conclusions can be drawn according to the research results. Chloride-free ecosterilizer and bleaching agent with an exposure of 15 and $20 \mathrm{~min}$ showed quite high efficiency in surface sterilization of explants of high-half blueberry and Arctic bramble. The explants viability of the studied berry plants was high during sterilization with a $0.1 \%$ mercuric chloride solution and an exposure of $15 \mathrm{~min}$, and it sharply decreased with an exposure of $20 \mathrm{~min}$.

An increase in the concentration of cytokinin 6-BAP from 0.5 to $1.0 \mathrm{mg} / \mathrm{L}$ on the WPM medium contributed to an increase in the number and total length of shoots of high-half blueberry and Arctic bramble, while the average shoot length slightly decreased. Therefore, it's advisable to add cytokinin 6-BAP at the concentration of $1.0 \mathrm{mg} / \mathrm{L}$ to the nutrient medium at the stage of micropropagation itself.

The number of roots of the studied berry plants increased, and its average root length decreased slightly with an increase in the concentration of IBA-derived auxin from 0.5 to $1.0 \mathrm{mg} / \mathrm{L}$. The total root length of high-half blueberry increased and decreased for Arctic bramble. Therefore, it is rational to add $1.0 \mathrm{mg} / \mathrm{L}$ of IBA-derived auxin for half-high blueberry, and $0.5 \mathrm{mg} / \mathrm{L}$ of IBA-derived auxin for Arctic bramble when cloning at the in vitro rooting stage.

\section{REFERENCES}

1. Гладкова Л.И. Выращивание голубики и клюквы. М.: ВНИИТЭИСХ. 1974. 64 с. [Gladkova L.I. Growing of Blueberry and Cranberry. Moscow, VNIITEISKh Publ., 1974. 64 p.].

2. Кощеев А.К., Смирняков, Ю.И. Лесные ягоды: справочник. М.: Экология, 1992. 270 c. [Koshcheyev A.K., Smirnyakov Yu.I. Wild Berries: A Handbook. Moscow, Ekologiya Publ., 1992. 270 p.].

3. Куминов Е.П. Нетрадиционные садовые культуры. Мичуринск, 1994. 358 с. [Kuminov E.P. Unconventional Garden Crops. Michurinsk, 1994. 358 p.]. 
4. Николаев И., Николаева Ю. Княженика - забытая ягода // Наука и жизнь. 1997. № 8. C. 130-131. [Nikolayev I., Nikolayeva Yu. Arctic Bramble - A Forgotten Berry. Nauka i Zhizn' [Science and Life], 1997, no. 8, pp. 130-131].

5. Тяк Г.В., Макаров С.С., Калашникова Е.А., Тяк А.В. Размножение и культивирование княженики арктической (Rubus arcticus L.) // Плодоводство и ягодоводство России. 2018. T. 52. C. 95-99. [Tyak G.V., Makarov S.S., Kalashnikova E.A., Tyak A.V. Reproduction and Cultivation of the Arctic Bramble (Rubus arcticus L.). Plodovodstvo i yagodovodstvo Rossii [Pomiculture and small fruits culture in Russia], 2018, vol. 52, pp. 95-99].

6. Тяк Г.В., Макеев В.А., Курлович Л.Е., Макеева Г.Ю., Тяк А.В. Перспективы культивирования и селекции лесных ягодных растений в Костромской области // Природа Костромского края: современное состояние и экомониторинг: материалы регион. конф. (Кострома, 24-25 марта 2017 г.). Кострома: Изд-во КГУ, 2017. С. 146-151. [Туак G.V., Makeev V.A., Kurlovich L.E., Makeeva G.Yu., TyakA.V. Prospects of Forest Berry Plants Cultivation and Breeding in the Kostroma Region. Proceedings of the Regional Conference "Nature of the Kostroma Region: Modern State and Ecomonitoring", Kostroma, March 24-25, 2017. Kostroma, 2017, pp. 146-151].

7. Черкасов А.Ф., Миронов К.А., Шутов В.В., Тяк Г.В., Веремьева С.С., Макеев В.А., Макеева Г.Ю., Рыжова Н.В. Недревесные лесные ресурсы Костромской области: дикорастущие плоды и ягоды, лекарственные растения и грибы: науч. моногр. / под ред. B.В. Шутова и др. Кострома: Изд-во КГТУ, 2006. 250 с. [Cherkasov A.F., Mironov K.A., Shutov V.V., Tyak G.V., Verem’yeva S.S., Makeyev V.A., Makeyeva G.Yu., Ryzhova N.V. NonTimber Forest Resources of the Kostroma Region: Wild Fruits and Berries, Medicinal Plants and Mushrooms: Scientific Monograph. Ed. by Shutov et al. Kostroma, KSTU Publ., 2006. 250 p.].

8. Blueberry Nursery Stock. Commercial Growers Catalog \& Price List. Oregon, Fall Creek Farm \& Nursery Inc., 2000. 20 p.

9. Bomser J., Madhavi D.L., Singletary K., Smith M.A.L. In Vitro Anticancer Activity of Fruit Extracts from Vaccinium Species. Planta Medica, 1996, vol. 62(3), pp. 212-216. DOI: $\underline{10.1055 / \mathrm{s}-2006-957862}$

10. Hildreth A.C. Propagation of the Lowbush Blueberry. American Society for Horticultural Science, 1929, vol. 26, pp. 91-92.

11. Jamieson A.R., Nickerson N.L. Field Performance of the Lowbush Blueberry Propagated by Seed, Stem Cuttings and Micropropagation. Acta Horticulturae, 2003, vol. 626, pp. 423-428. DOI: 10.17660/ActaHortic.2003.626.58

12. Karp K., Starast M., Värnik R. The Arctic Bramble (Rubus arcticus L.) - The Most Profitable Wild Berry in Estonia. Baltic Forestry, 1997, vol. 3, no. 2, pp. 47-52.

13. Noormets M., Karp K., Paal T. Recultivation of Opencast Peat Pits with Vaccinium Culture in Estonia. WIT Transactions on Ecology and the Environment. Vol. 64: Ecosystems and Sustainable Development IV, 2003, vol. 2, pp. 1005-1014. DOI: 10.2495/ECO030242

14. Paal T. Cultivation of Vaccinium angustifolium from Seed. Proceedings of the International Conference "Problems of Rational Utilization and Reproduction of Berry Plants in Boreal Forests on the Eve of the 21 Century”, Glubokoye-Gomel, Belarus, September 11-15, 2000. Gomel, Forest Institute NASB, 2000, pp. 193-196.

15. Pirinen H., Dalman P., Kärenlampi S., Tammisola J., Kokko H. Description of Three New Arctic Bramble Cultivars and Proposal for Cultivar Identification. Agricultural and Food Science in Finland, 1998, vol. 7, no. 4, pp. 455-468. DOI: 10.23986/afsci.5608

16. Ragnar M., Rytkönen P., Hedh J. Akkerbär. Luleå, Sweden, Black Island Books, 2017. 169 p.

17. Read P.E., Economou A.S., Hartley C.A., Grout J.M., Fellman C.D. A Summary of Stock Paint Influences on Woody Plant Tissue Culture Success with Special Emphasis 
on the Ericaceae. Acta Horticulturae, 1988, vol. 227, pp. 476-478. DOI: 10.17660/ ActaHortic.1988.227.98

18. Strik B.C., Yarborough D.E. Blueberry Production Trends in North America, 1992 to 2003, and Predictions for Growth. HortTechnology, 2005, vol. 15, iss. 2, pp. 391-398. DOI: 10.21273/HORTTECH.15.2.0391

19. Vahejõe K., Albert T., Noormets M., Karp K., Paal T., Starast M., Värnik R. Berry Cultivation in Cutover Peatlands in Estonia: Agricultural and Economical Aspects. Baltic Forestry, 2010, vol. 16, no. 2(31), pp. 264-272.

20. Yarborough D.E. Cultivated Lowbush Blueberry (Vaccinium angustifolium) Establishment and Management. Journal of Jilin Agricultural University, 2009, vol. 31(5), pp. 556-560.

\section{ПОЛУЧЕНИЕ ВЫСОКОКАЧЕСТВЕННОГО \\ ПОСАДОЧНОГО МАТЕРИАЛА ЛЕСНЫХ ЯГОДНЫХ РАСТЕНИЙ МЕТОДОМ КЛОНАЛЬНОГО МИКРОРАЗМНОЖЕНИЯ ДЛЯ РЕКУЛЬТИВАЦИИ ВЫРАБОТАННЫХ ТОРФЯНИКОВ}

C.С. Макаровㄹ, канд. с.-х. наук, ст. науч. сотр.; ResearcherID: AAB-4651-2021, ORCID: https://orcid.org/0000-0003-0564-8888

И.Б. Кузнецова ${ }^{2}$ канд. с.-х. наук, доц.; ResearcherID: AAB-4568-2021, ORCID: https://orcid.org/0000-0001-5011-3271

А.И. Чудецкий', вед. инж.; ResearcherID: H-1210-2019, ORCID: https://orcid.org/0000-0003-4804-7759

C.A. Родин ${ }^{3}$ д-р с.-х. наук, акад. РАН, заместитель директора по НИР; ORCID: https://orcid.org/0000-0002-8947-9809

'Центрально-европейская лесная опытная станция ВНИИЛМ, просп. Мира, д. 134, г. Кострома, Россия, 156013; e-mail: makarov_serg44@mail.ru, a.chudetsky@mail.ru

2Костромская государственная сельскохозяйственная академия, Учебный городок, д. 34, Караваевская с/а, п. Караваево, Костромской р-н, Костромская обл., Россия, 156530; e-mail: sonnereiser@yandex.ru

${ }^{3}$ Всероссийский научно-исследовательский институт лесоводства и механизации лесного хозяйства, ул. Институтская, д. 15, г. Пушкино, Московская обл., Россия, 141202

Аннотация. Приведены результаты исследований по совершенствованию технологии получения высококачественного посадочного материала голубики полувысокой и княженики арктической методом клонального микроразмножения. Создание плантации лесных ягодных растений в районах добычи торфа позволяет снизить ущерб, наносимый окружающей среде, и значительно повысить эффективность лесной промышленности. В последние десятилетия в России и других странах мира растет интерес к созданию на осушенных и освоенных торфяниках насаждений лесных ягодных растений, для успешного выращивания которых в промышленных масштабах необходимо использовать сортовой посадочный материал. Наиболее эффективный метод (из вегетативных) его разведения - клональное микроразмножение, позволяющее в условиях небольшой лабораторной площади круглый год получать огромное количество оздоровленного посадочного материала. Экостерилизатор бесхлорный и отбеливающее средство на основе гипохлорита натрия «Белизна» показали высокую эффективность при стерилизации эксплантатов голубики полувысокой и княженики арктической с выдержкой 15 и 20 мин. Наиболее высокая жизнеспособность эксплантов исследуемых лесных ягодных культур отмечена при стерилизации $0,1 \%$ раствором хлорида ртути и 
выдержке 15 мин, низкая - при выдержке 20 мин. На стадии собственно микроразмножения при повышении концентрации цитокинина 6-БАП с 0,5 до 1,0 мг/л на питательной среде WPM увеличивалось количество побегов у регенерированных растений голубики полувысокой (сортов Northcountry и Northblue) и княженики арктической (сортов Anna и Sofia). На стадии укоренения in vitro отмечено влияние концентрации ауксина ИМК на количество и длину корней регенерированных растений.

Для цитирования: Makarov S.S., Kuznetsova I.B., Chudetsky A.I., Rodin S.A. Obtaining High-Quality Planting Material of Forest Berry Plants by Clonal Micropropagation for Restoration of Cutover Peatlands // Изв. вузов. Лесн. журн. 2021. № 2. C. 21-29. DOI: 10.37482/0536-1036-2021-2-21-29

Ключевые слова: княженика арктическая, клональное микроразмножение, сорт, выработанные торфяники, регулятор роста, голубика полувысокая, in vitro.

Авторы заявляют об отсутствии конфликта интересов The authors declare that there is no conflict of interest

Поступила 05.02.20 / Received on February 5, 2020 